Journal Of Al Azhar University Engineering Sector

Vol. 13, No. 46, January, 2018, 30-45

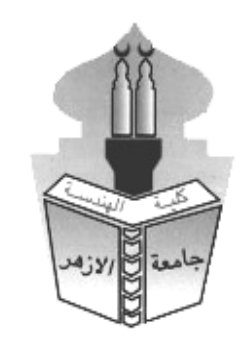

\title{
EXPERT SYSTEM DEVELOPMENT FOR EVALUATING COMPETITION ABILITY OF EGYPTIAN CONSTRUCTION COMPANIES IN INFRASTRUCTURE TENDERS
}

\author{
Ibrahim A. Nosair ${ }^{1}$, Ahmed A. Elsaid ${ }^{1}$ and Manal S. Abdelhamid ${ }^{2}$ \\ ${ }^{1}$ Faculty of Engineering Ain shames University, Egypt. \\ ${ }^{2}$ Housing and Building National Research Center (HBRC), Egypt.
}

\begin{abstract}
This study attempts to shed a great deal of light on the problem of contractor selection in the Egyptian infrastructure projects. This paper presents a comprehensive review of the available literature on contractor selection methods. Reviewing the literature we found that there are thirteen criteria that must be taken into consideration when evaluating the competition ability (i) Financial ;(ii) Health and Safety ;(iii) Technical; ;(iv) Quality;(v) Organization ;(vi) Relationship ;(vii) Past Experience ;(viii) Past Performance ;(ix) Resources ;(x) Environmental ;(xi) Management ; (xii) Present workload ;( (xiii) Tendering price. The thirteen criteria have twenty seven sub-criteria that are collected from previous studies that influence the competition ability. The objective of this research is to study the contractor selection process and to develop an expert system that aids in assessing contractor selection in infrastructure tenders in Egypt. Interviews with domain experts were arranged. The results of questionnaire surveys have been analyzed in order to extract the knowledge which subsequently used to develop the expert system for tenders evaluation (ES-TE). The system was tested against three actual cases and it is found that the system is valid for assessing the contractor selection in infrastructure tenders in Egypt. Finally, the expert program facilitates contractor selection instead of human judgment.
\end{abstract}

Keywords: Contractor selection, competition ability, Infrastructure, Egypt, Criteria, Expert system.

\section{INTRODUCTION}

Contractor selection has been a much debated issue over the past ten years. Clients are most often constrained to select the lowest bidder by Egyptian law 89/1998. On the Other hand, it is indisputable that reliance on bid prices alone as the discriminating factor between bidders alone is quite risky and short-sighted, and may lead to the failure of the project in terms of poor contractor performance and prolonged construction duration. Therefore, choosing a competent construction contractor is one of the most important tasks faced by client that usually has a significant impact on the success of a project and the achievement of best value for money.

This research aims to study the contractor selection process and to develop an expert system that aids in assessing contractor selection in infrastructure tenders in Egypt. 
HATUSH AND SKITMORE 1997a have classified five categories for assessing contractor competitiveness were financial soundness, technical ability, management capability, health and safety and reputation [1].

(Herbert and Biggert 1993 ) have investigated criteria for selecting suitable contractor for job were management capability, relationships, occupational health and safety, claim and financial status[2].

Twenty seven sub criteria that are clustered in thirteen criteria are considered in the survey to calculate a relative weight for every sub criteria to be a reference in companies' evaluation. These criteria and sub criteria were gathered from the literature review [3-9].

\section{Research Objectives}

Assessing the competition ability criteria and sub criteria through developing the following

1. The weight for thirteen criteria (Financial, Health and Safety, Technical, Quality, Organization, Relationship, Past Experience, Past Performance ,Resources , Environmental, Management, Present workload, Tendering price).

2. The relative weight for twenty seven sub criteria (Size of past project completed, Type of past project completed, Adequacy of labour resources, QA/QC programs, Adequacy of plant \& equipment's ,Present workload, Construction program, Construction method, Environmental plan ,...) to be a reference in companies' evaluation.

3. A Framework to evaluate and rank the bidders in infrastructure project tenders.

4. An expert system for evaluating Competition ability for construction contractors in infrastructure projects.

\section{Research Methodology}

- Review of literature in the field of Competition ability of construction companies.

- Determining the sample size of infrastructure projects in Egypt.

- Data collection through a questionnaire distributed on 23 expert from the field of construction industry (owners, consultants and contractors) and data includes (Size of past project completed, Type of past project completed, Adequacy of labour resources, QA/QC programs, Adequacy of plant \& equipment's ,Present workload, Construction program, Construction method, Environmental plan ,...) from Clients, Consultants and Contractors.

- Analysis of surveyed data and calculating a relative weight for every sub criteria to be a reference in companies' evaluation.

- Developing a Framework to evaluate and rank the bidders in infrastructure project tenders.

- Expert system development for evaluating Competition ability for construction contractors in infrastructure projects tenders

- System implementation on three cases study to verify its accuracy.

- Extracting conclusion and recommendations for further studies.

\section{QUESTIONNAIRE DESIGN}

The questionnaire is divided into three parts. The first part contained questions about construction firm for(firm type, firm experience, firm specialization), the second part included questions about the weight for Competition ability criteria and the third part include questions about degree of importance of the Competition ability sub-criteria based on their professional judgment on a given five points Likert-type scale ( where $1=$ very low importance, $2=$ low importance, $3=$ medium importance, $4=$ high importance, $5=$ very high importance. At the end of each group of sub-criteria, the chance was given to respondents to add and rate any competition ability sub-criteria 
A total number of 38 questionnaires (where, the response rate was slowly in the beginning) were distributed on Egyptian construction companies during the period from March 2014 to August 2015 The distribution was carried out as following: 10 questionnaires were mailed and the rest were delivered personally. Throughout the interview the purpose of research and the main questions in the questionnaire have been explained. The questionnaires were filled by top and middle level managers, project managers. A total of 23 out of 38 questionnaires were returned and were ready to be analyzed. By using SPSS software V.16, the main statistical analysis was descriptive analysis.

\subsection{Calculation of sub criteria Relative weight.}

Twenty seven sub criteria are considered in the survey to determine the most important sub criteria in selecting contractors. By using SPSS software to provide mean score of criteria and sub criteria was determined in Table 1 which shows the most important sub criteria.

The mean value of scores ranges from 3.30 Contract cost overruns to 4.52 QA/QC programs, also it can be noticed that there is a small standard deviation that ranges from 0.662 to 1.486 referring to the responses are clustered closely around the mean [10].

Table 1 Relative weight of technical sub criteria.

\begin{tabular}{|c|c|c|c|c|c|c|}
\hline ID & Sub criteria & $\begin{array}{c}\text { Mean } \\
\text { score } \\
\text { A }\end{array}$ & $\begin{array}{l}\text { sum of } \\
\text { sub } \\
\text { criteria } \\
\text { B }\end{array}$ & $\begin{array}{c}\text { Ratio } \\
\text { of sub } \\
\text { criteria } \\
\text { C }\end{array}$ & $\begin{array}{c}\text { Criteria } \\
\text { Weight } \\
\text { D }\end{array}$ & $\begin{array}{c}\text { Relative } \\
\text { weight } \\
\text { Of sub } \\
\text { criteria }\end{array}$ \\
\hline FC1 & Financial stability & 4.39 & \multirow[t]{3}{*}{12.7} & 0.35 & \multirow[t]{3}{*}{3.83} & 1.324 \\
\hline $\mathrm{FC} 2$ & Financial Status & 4.09 & & 0.32 & & 1.233 \\
\hline FC3 & $\begin{array}{l}\text { Banking arrangement and } \\
\text { bonding }\end{array}$ & 4.22 & & 0.33 & & 1.273 \\
\hline SC1 & Health and safety records & 3.74 & \multirow[t]{2}{*}{7.96} & 0.47 & \multirow[t]{2}{*}{2.7} & 1.27 \\
\hline $\mathrm{SC} 2$ & Safety policy & 4.22 & & 0.53 & & 1.43 \\
\hline $\mathrm{TC} 1$ & Construction method & 4.48 & \multirow[t]{2}{*}{9.00} & 0.49 & \multirow[t]{2}{*}{3.74} & 1.81 \\
\hline $\mathrm{TC} 2$ & Construction program & 4.52 & & 0.51 & & 1.93 \\
\hline QC1 & Past quality performance & 4.22 & \multirow[t]{2}{*}{8.74} & 0.48 & \multirow[t]{2}{*}{4.09} & 1.97 \\
\hline $\mathrm{QC2}$ & QA/AC programs & 4.52 & & 0.52 & & 2.12 \\
\hline OC1 & Size of the organization & 3.91 & \multirow[t]{3}{*}{11.08} & 0.35 & \multirow[t]{3}{*}{2.78} & 0.98 \\
\hline $\mathrm{OC} 2$ & Length of time in business & 3.74 & & 0.34 & & 0.94 \\
\hline OC3 & Experience in the region & 3.43 & & 0.31 & & 0.86 \\
\hline $\mathrm{RC} 1$ & Relationship with project clients & 4.43 & \multirow[t]{2}{*}{8.47} & 0.52 & \multirow[t]{2}{*}{2.7} & 1.41 \\
\hline $\mathrm{RC} 2$ & Relationship with the Designers & 4.04 & & 0.48 & & 1.29 \\
\hline PEC1 & Type of past project completed & 4.39 & \multirow[t]{2}{*}{8.82} & 0.50 & \multirow[t]{2}{*}{4.65} & 2.31 \\
\hline PEC2 & Size of past project completed & 4.43 & & 0.50 & & 2.34 \\
\hline PPC1 & $\begin{array}{l}\text { Failure to have completed a } \\
\text { contract }\end{array}$ & 4.13 & \multirow[t]{4}{*}{15.3} & 0.27 & \multirow[t]{4}{*}{3.91} & 1.06 \\
\hline PPC2 & Contract time overruns & 4.00 & & 0.26 & & 1.02 \\
\hline PPC3 & Contract cost overruns & 3.30 & & 0.22 & & 0.84 \\
\hline PPC4 & Past record of conflict and & 3.87 & & 0.25 & & 0.99 \\
\hline
\end{tabular}




\begin{tabular}{|c|c|c|c|c|c|c|}
\hline & disputes & & & & & \\
\hline RC1 & Adequacy of labour resources & 4.48 & 8.83 & 0.51 & 4.17 & 2.12 \\
\cline { 1 - 2 } RC2 & $\begin{array}{c}\text { Adequacy of plant } \\
\text { \&equipment's }\end{array}$ & 4.35 & & & & \\
& Experience of technical staff & 4.26 & 8.69 & 0.49 & 2.96 & 1.45 \\
\hline MC2 & Staff qualification & 4.43 & & 0.51 & & 1.51 \\
\hline EC1 & Environmental plan & 4.04 & 4.04 & 1.00 & 1.72 & 1.72 \\
\hline PC1 & Present workload & 4.00 & 4 & 1.00 & 1.93 & 1.93 \\
\hline
\end{tabular}

\section{SYSTEM COMPONENTS}

The system consists of five main components, which interact via a user interface that controls the connectivity among those components. The components are:

System Input: it acquires project information (e.g., contractor selection criteria, tender law, etc.) which has great impact on contractor selection.

Tender Attribute Module: it defines contractor selection criteria and their relevant sub-criteria in order to evaluate each bidder technically and financially and rank the bidders.

Tender Procedure Module: it reviews the submitted tender documents from each bidder comply with tender law. This module interacts with the tender procedures stated in Egyptian law 89/1998, investment law 2010 and FIDIC tender procedure.

Tender Analyzer Module: it analyzes the tender considering the information acquired in the tender procedure and attribute modules. This module presents a conclusion and illustrates the reasons that lead to the decision.

System Output: it provides the assessment of the tender in a form of summary report.

\section{Building Expert system tender evaluation ES-TE}

ES-TE was built utilizing JAVA programming language and MYSQL due to its simplicity in building either the system's screens or coding the rules (i.e., "if" condition).

System's screens were designed to gather the session information from the system user. The input screens were divided into four groups:

1) "User Information" in which the user should provide the system with his personal information as well as user name, user company and user position.

2) "Project data" input screens in which the user would be asked to inform the system with the project name, description, bidders name, bidder price and tender law.

3) "Tender data" screen in which the user should answer some questions needed to evaluate the bidders.

4) "Tender Procedure Data" screen in which the user should inform the system regarding the procedure had been followed by tender committee in handling the tender documents.

After designing the input screens, more than 257 IF-THEN rules had been developed in order to track all possible paths in the system. All the rules were linked with the output reporting module. The output screen provides the user with a summary report for the session conclusion.

\subsection{ES-TE User Interfaces}

System interfaces screens are designed in a way that allows its users to navigate the system in easy manner. Once ES-TE is activated, it provides different options allowing to start a new session or to open an existing one (previously analyzed and saved). To ensure completeness of required data, the system doesn't allow the user to move from screen to another before answering all questions stated in that screen. Full explanations for each designed interface screen are presented in the following sections.

\subsubsection{Information and Project Data}


After start up screen (see Figure 1). Then the program goes to the next window session information (first part). The user will enter user name, user Company, user position and tender reference (see Figure 2).

Then the program goes to the next window; session information (second part). In this window the user will enter bidders' names and tender description, bidder price in addition to identifying tender law (see Figure 3).

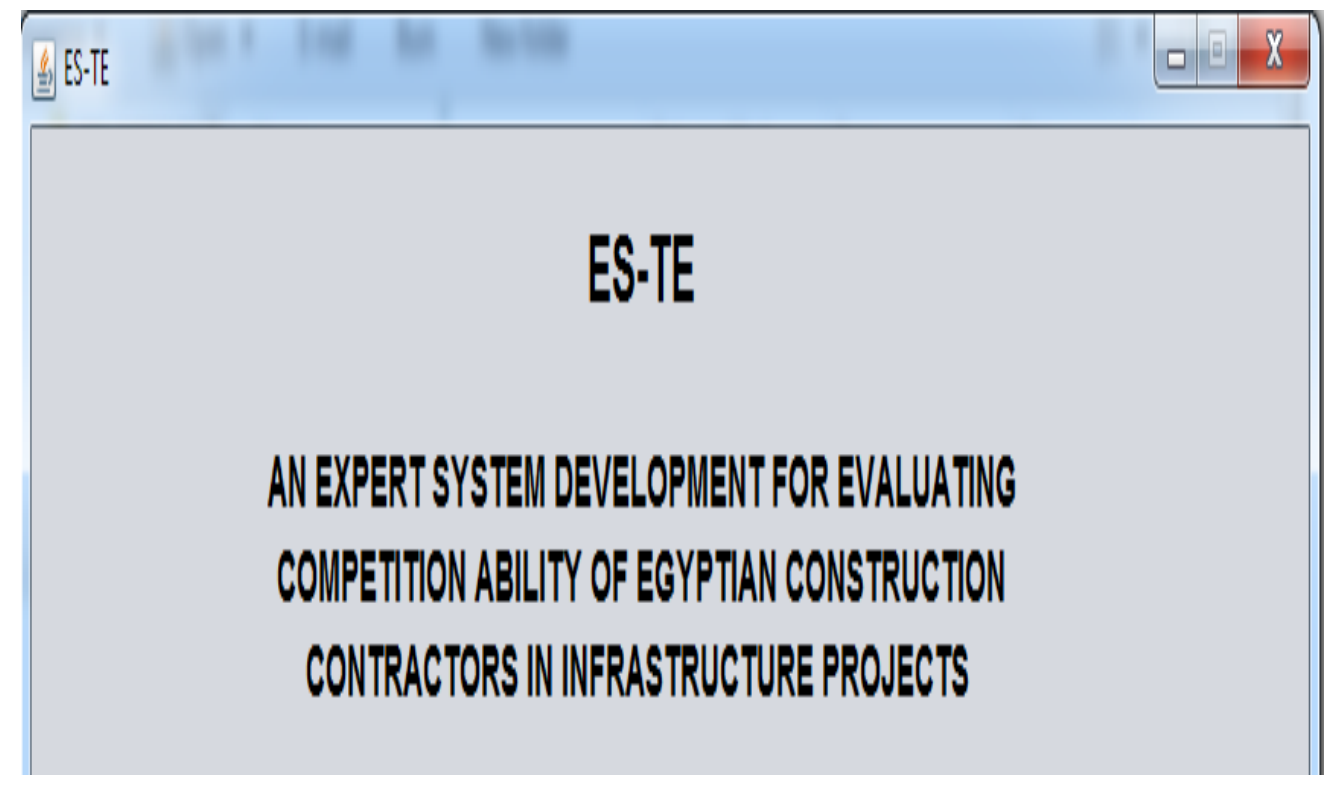

Fig. 1 Startup screen

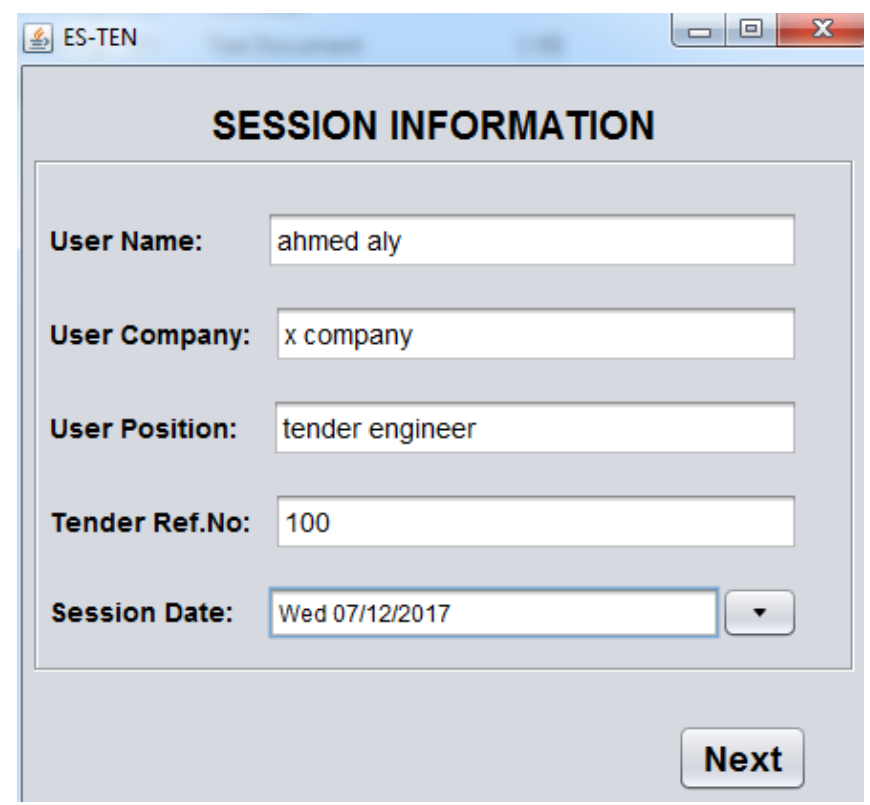

Fig. 2 User information interface screen 


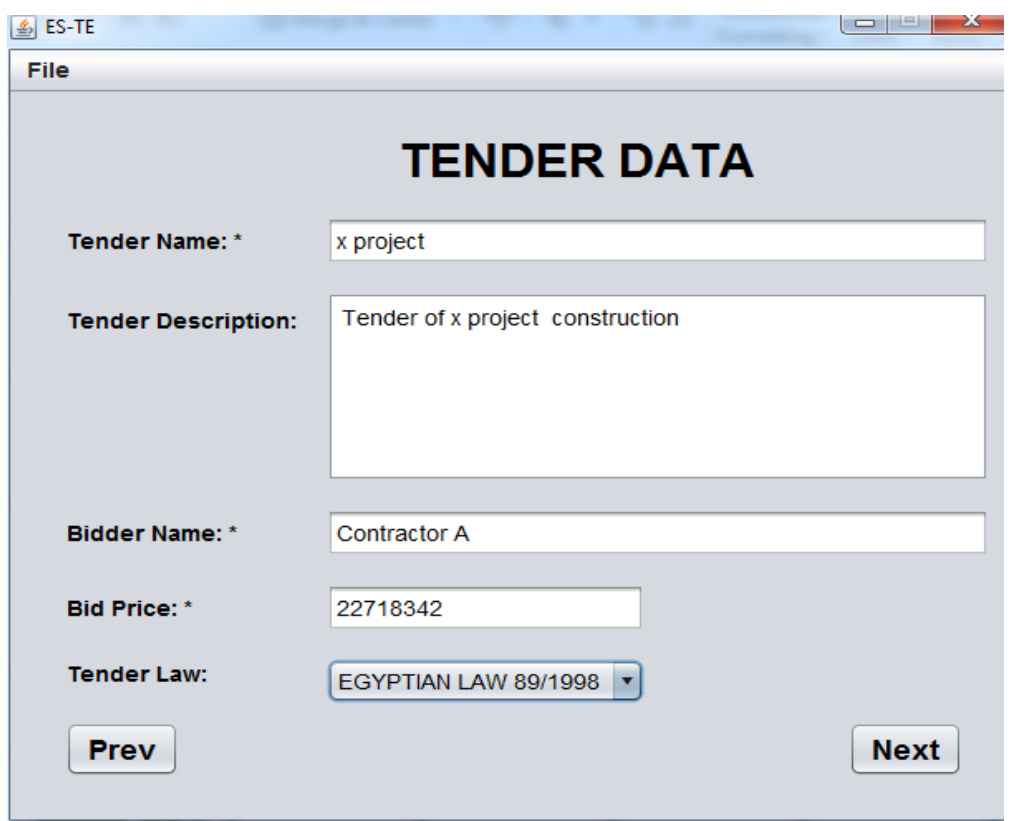

Fig. 3 Tender data interface screen

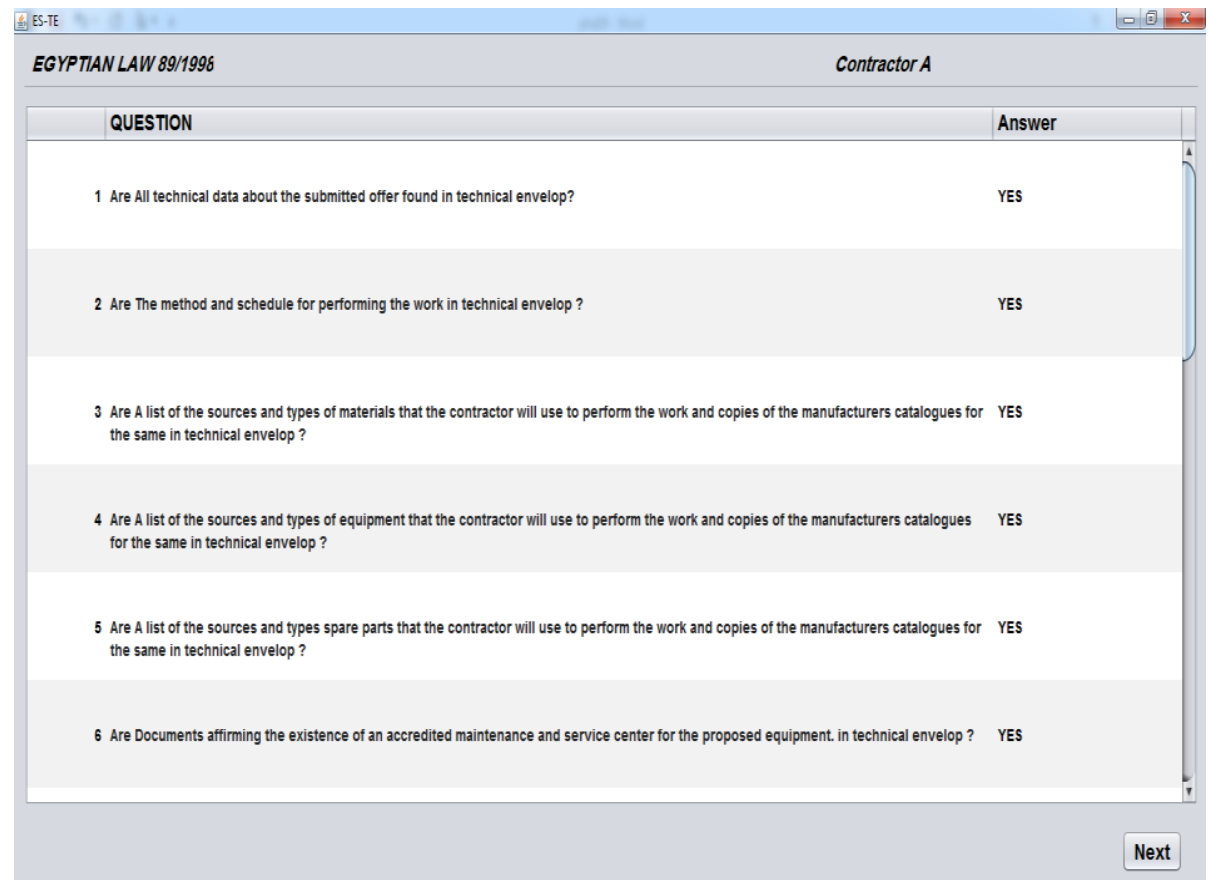

Fig. 4 Tender procedure interface screen

\subsubsection{Tender procedure}

Then the program goes to the next window; tender procedure to enter the requirement of Egyptian law 89/1996 (see Figure 4).

6.1.3 Financial aspects

Then the program goes to the next window; Financial aspects which used to enter status for current and fixed assets, status for liquidity, status for Annual turnover, status for balance sheet statement, status for Income statement, status for funds and status for bonds (see Figure 5). 


\subsubsection{Health and safety}

Then the program goes to the next window; Health and safety. The user will enter number of accidents for the past 5 years, status for scaffolding protection, status for opening protection, status for first aid, status for personal protection, status for safety staff and status for tools \& equipment protection (see Figure 6).

\subsubsection{Technical aspects}

Then the program goes to the next window; Technical aspects. In this window The user will enter status for construction steps, status for manpower needed, status for plant \& equipment needed, status for materials needed, status for duration of activities, status for relationship between activities and status for Resources (see Figure 7).

\subsubsection{Quality}

Then the program goes to the next window; quality. The user will enter status for quality of work on past projects, status for quality of workmanship, available of QA/QC program (Yes -no) and Available of Quality certificate (Yes. No) (see Figure 8).

\subsubsection{Organization}

Then the program goes to the next window organization. The user will enter status for number of departments and jobs and relationship between them, No. of contractor years in business and Contractor has an experience in the region (yes-No) (see Figure 9).

\subsubsection{Relationship}

Then the program goes to the next window relationship. The user will enter status of relationship with previous clients and status of relationship with previous designers (see Figure 10).

\subsubsection{Past Experience}

Then the program goes to the next window past experience. The user will enter no. of projects completed with the same type and no. of projects completed with the same size (see Figure 11).

\subsubsection{Past Performance}

Then the program goes to the next window Past performance. The user will enter no. of previous contracts failed to be completed, no. of contract time overruns, no. of contract cost overruns, no. of past claims submitted by contractor, no. of past claims submitted by contractor and approved, no. of past claims submitted against contractor and no. of past claims submitted against contractor and approved (see Figure 12).

\subsubsection{Resources}

Then the program goes to the next window resources. The user will enter the status for availability of first level supervisors, status for availability of skilled crafts, status for equipment Model- Make -capacity, percentage of owing equipment and status for adequate plant and equipment to do the work properly(see Figure 13).

\subsubsection{Environmental aspects}

Then the program goes to the next window Environmental aspects. The user will enter if the bidder provides environmental plan comply with Egyptian environmental law (yes or No) (see Figure 14).

\subsubsection{Management}

Then the program goes to the next window management. The user will enter No. of years' Experience for technical staff, Status for Suitable Computer skill, Status for Suitable Language, Status for Suitable educational degree and Status for Suitable technical courses (see Figure 15). 
EXPERT SYSTEM DEVELOPMENT FOR EVALUATING COMPETITION ABILITY OF EGYPTIAN CONSTRUCTION COMPANIES IN INFRASTRUCTURE TENDERS

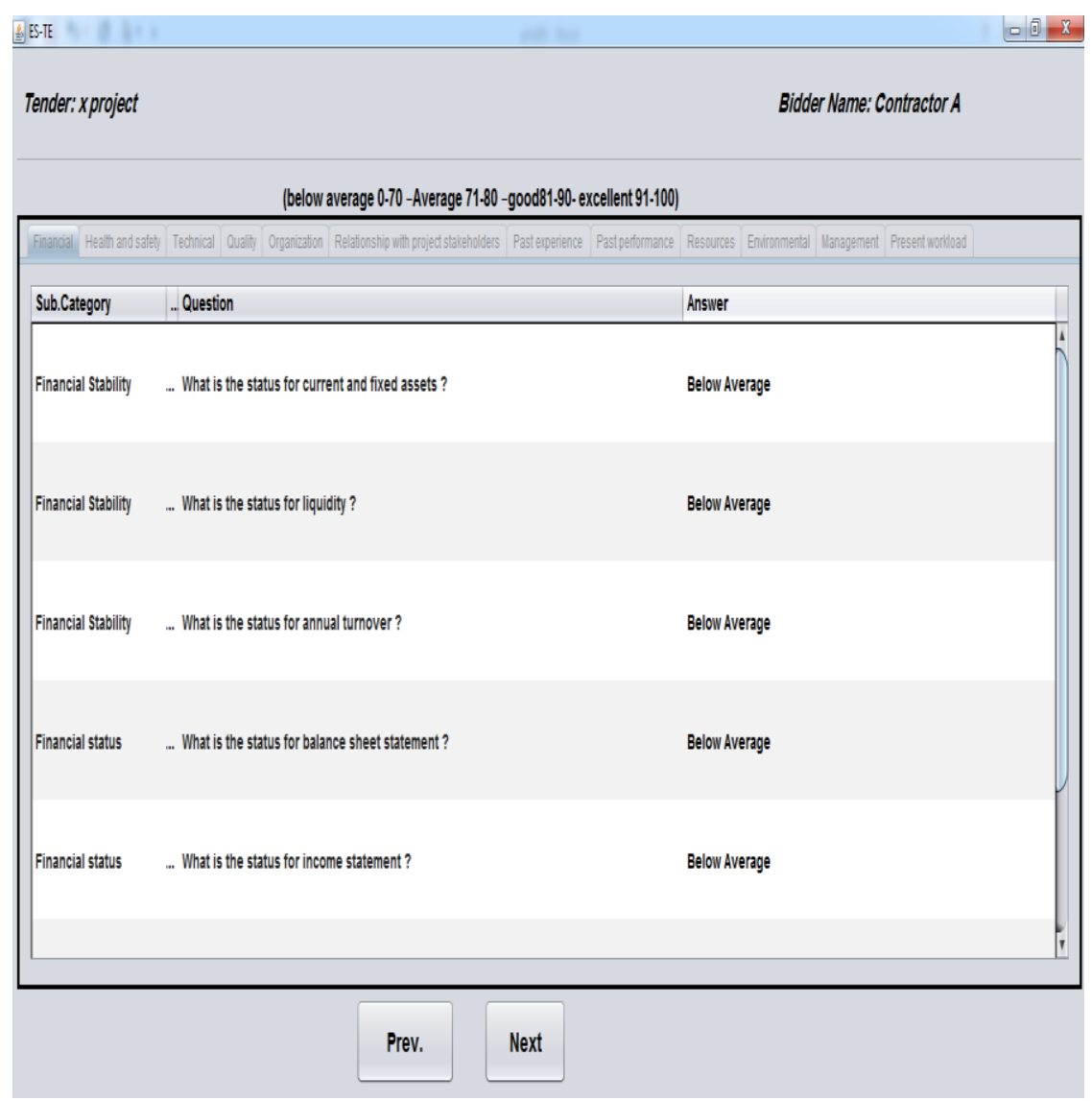

Fig. 5 financial sub criteria interface screen

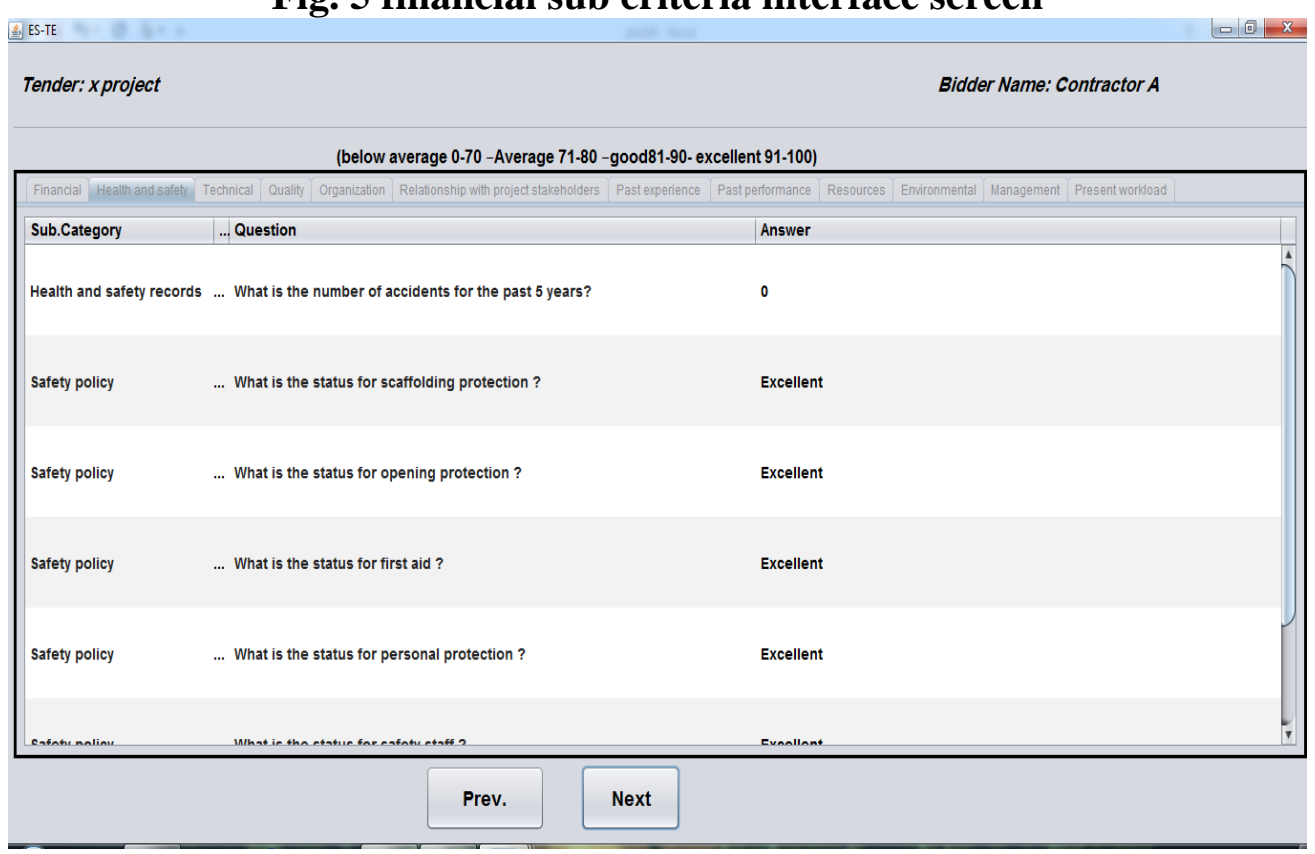

Fig.6 Health and safety sub criteria interface screen 
EXPERT SYSTEM DEVELOPMENT FOR EVALUATING COMPETITION ABILITY OF EGYPTIAN CONSTRUCTION COMPANIES IN INFRASTRUCTURE TENDERS

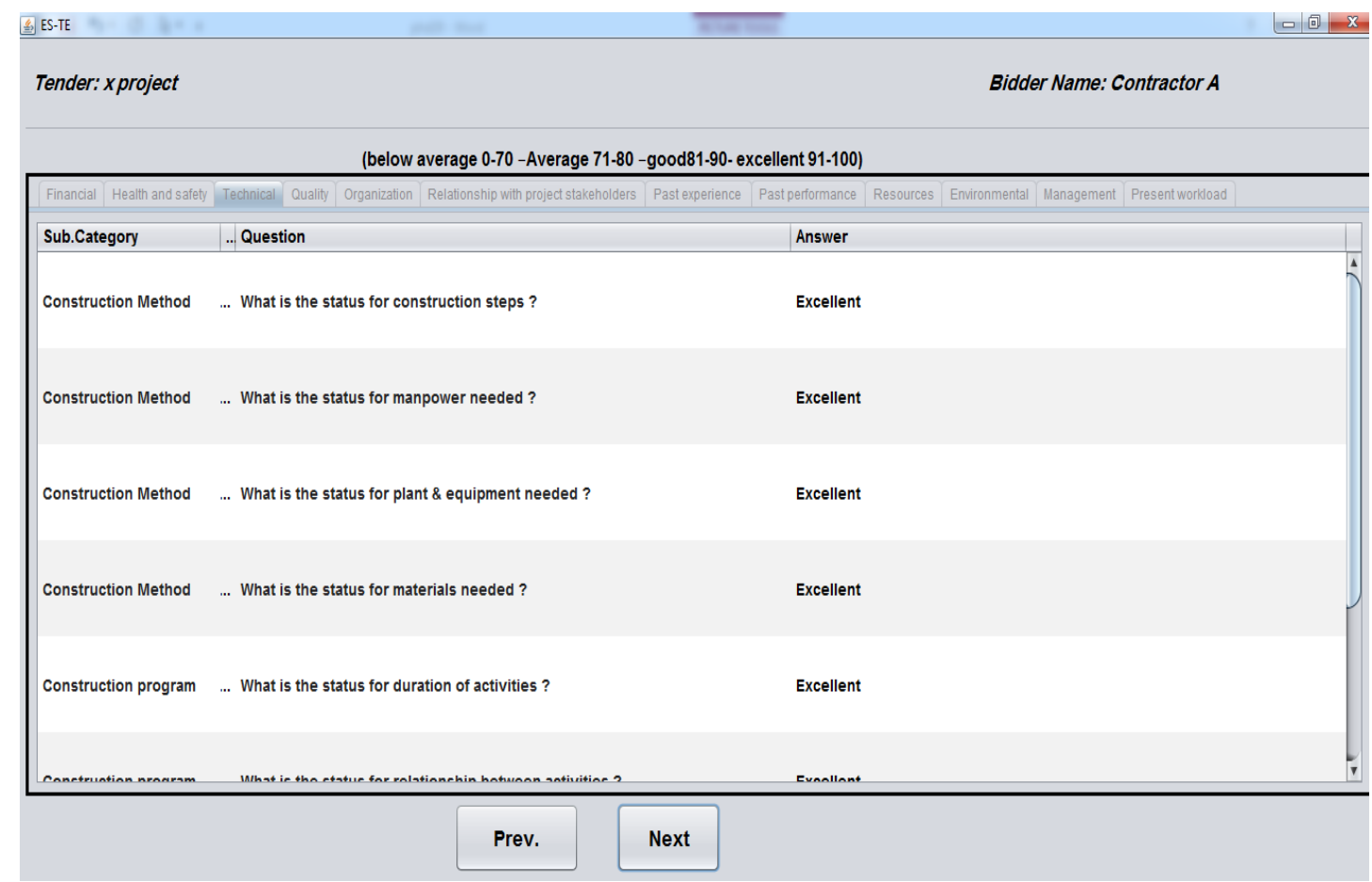

Fig. 7 Technical sub criteria interface screen

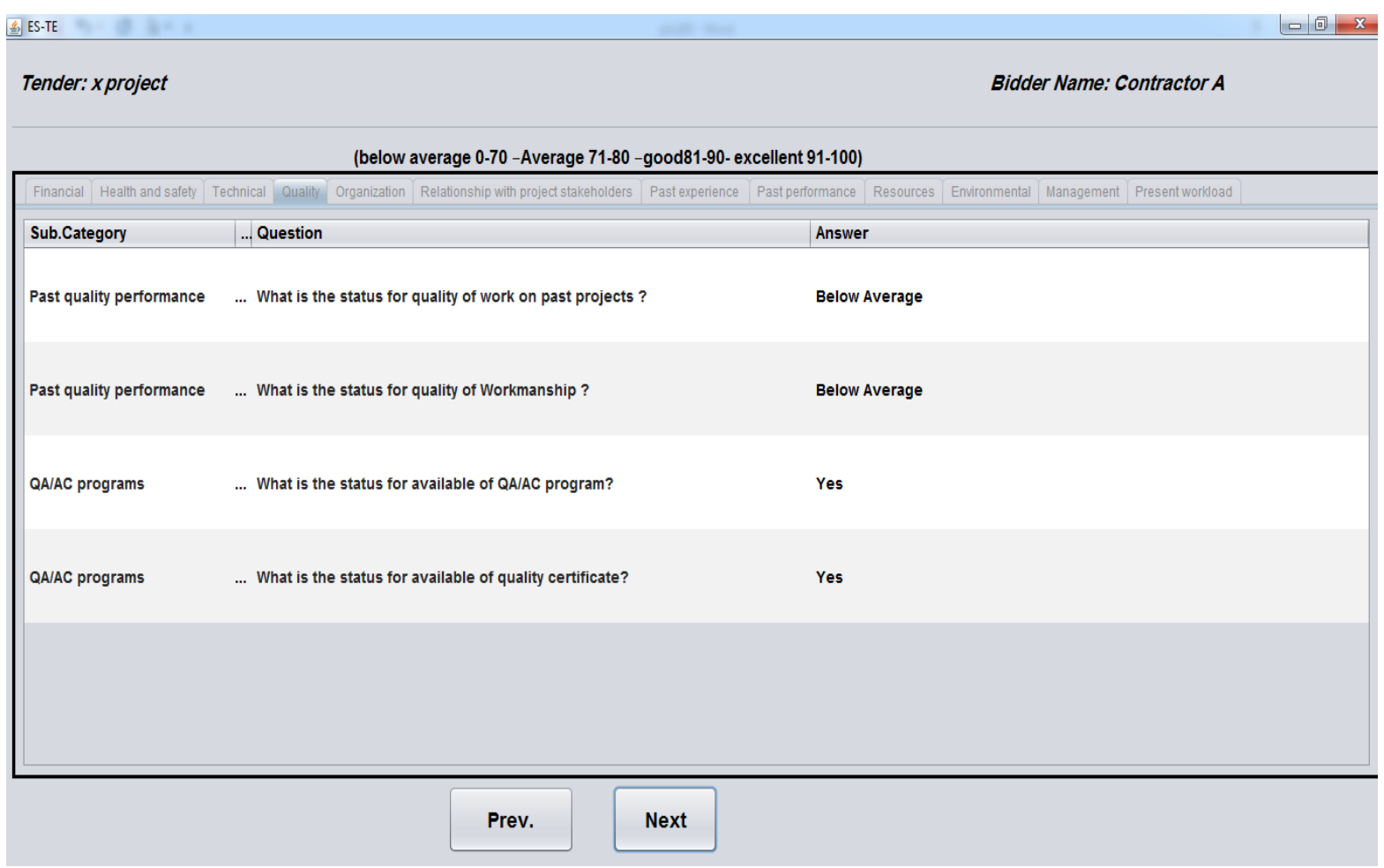

Fig.8 Quality sub criteria interface screen 
EXPERT SYSTEM DEVELOPMENT FOR EVALUATING COMPETITION ABILITY OF EGYPTIAN CONSTRUCTION COMPANIES IN INFRASTRUCTURE TENDERS

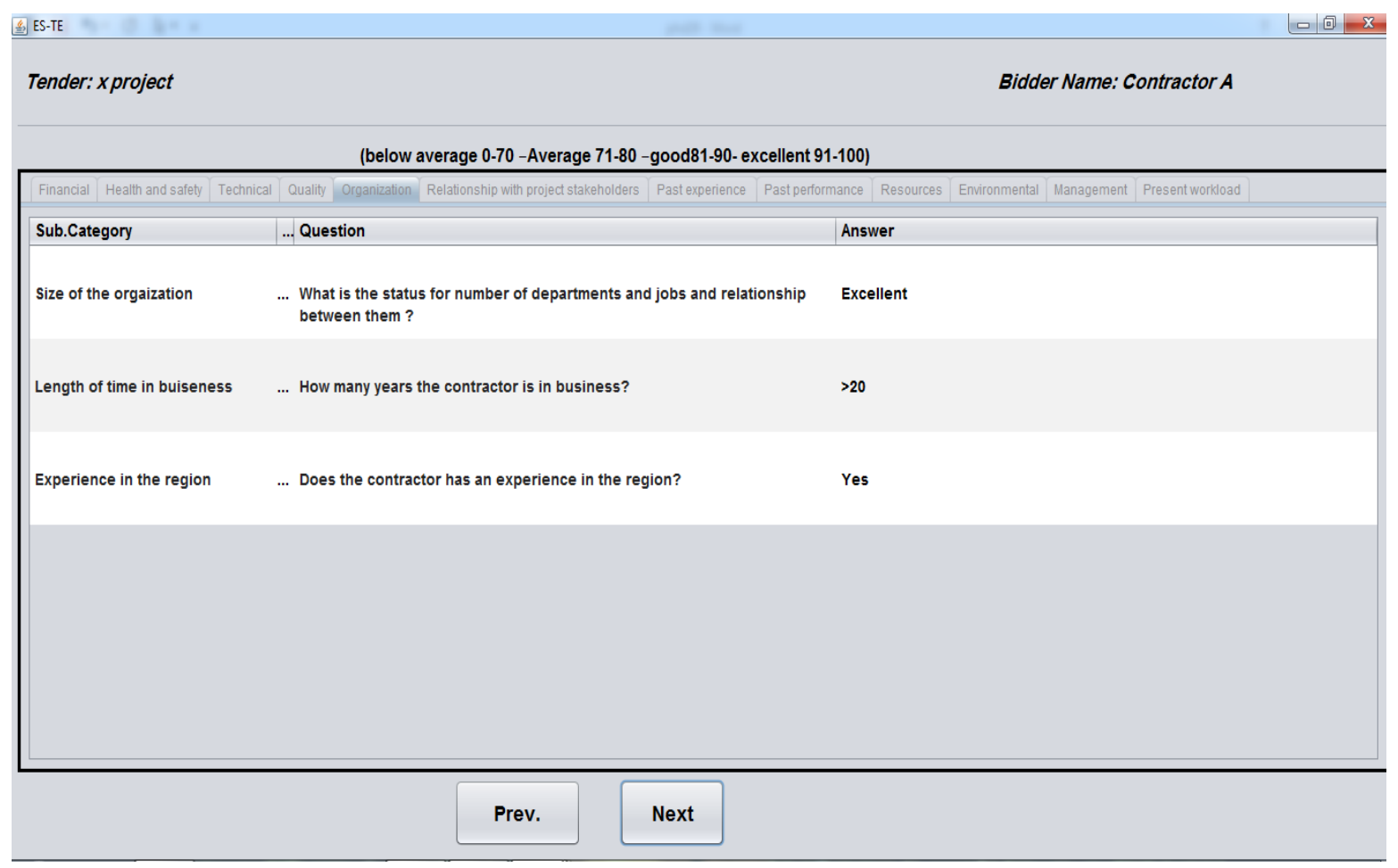

Fig. 9 Organization sub criteria interface screen

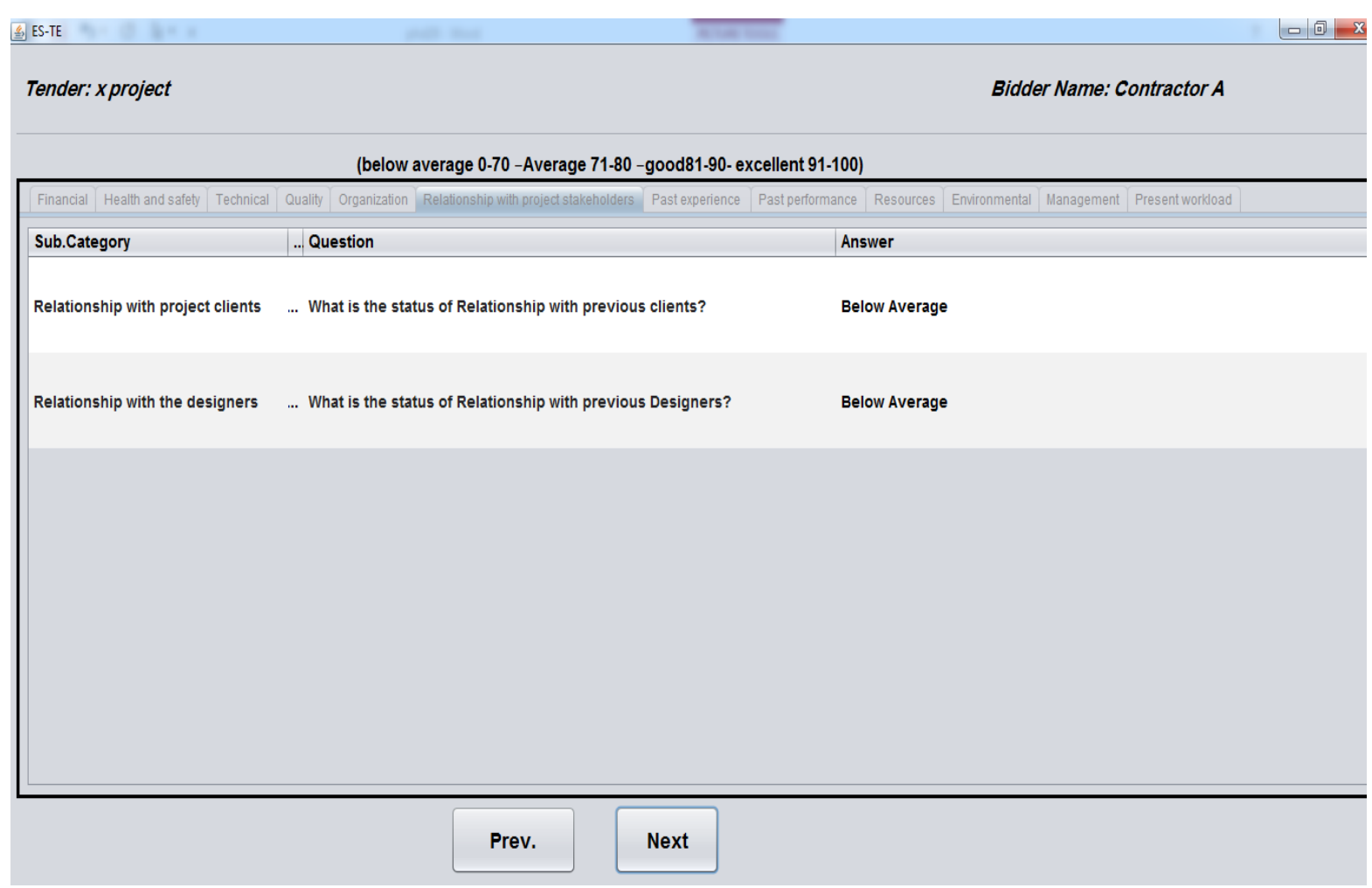

Fig. 10 Relationship sub criteria interface screen 


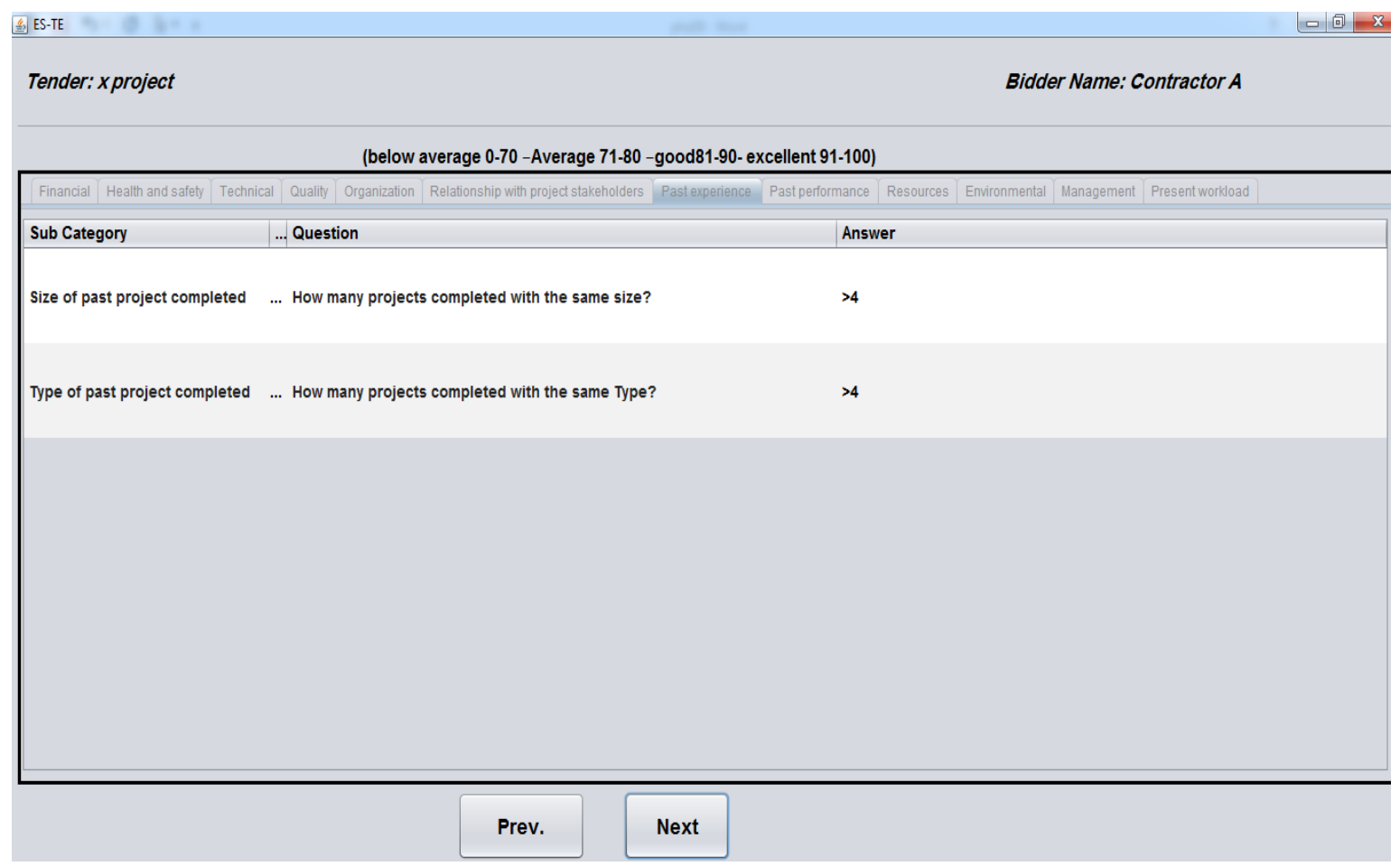

Fig. 11 past experience sub criteria interface screen

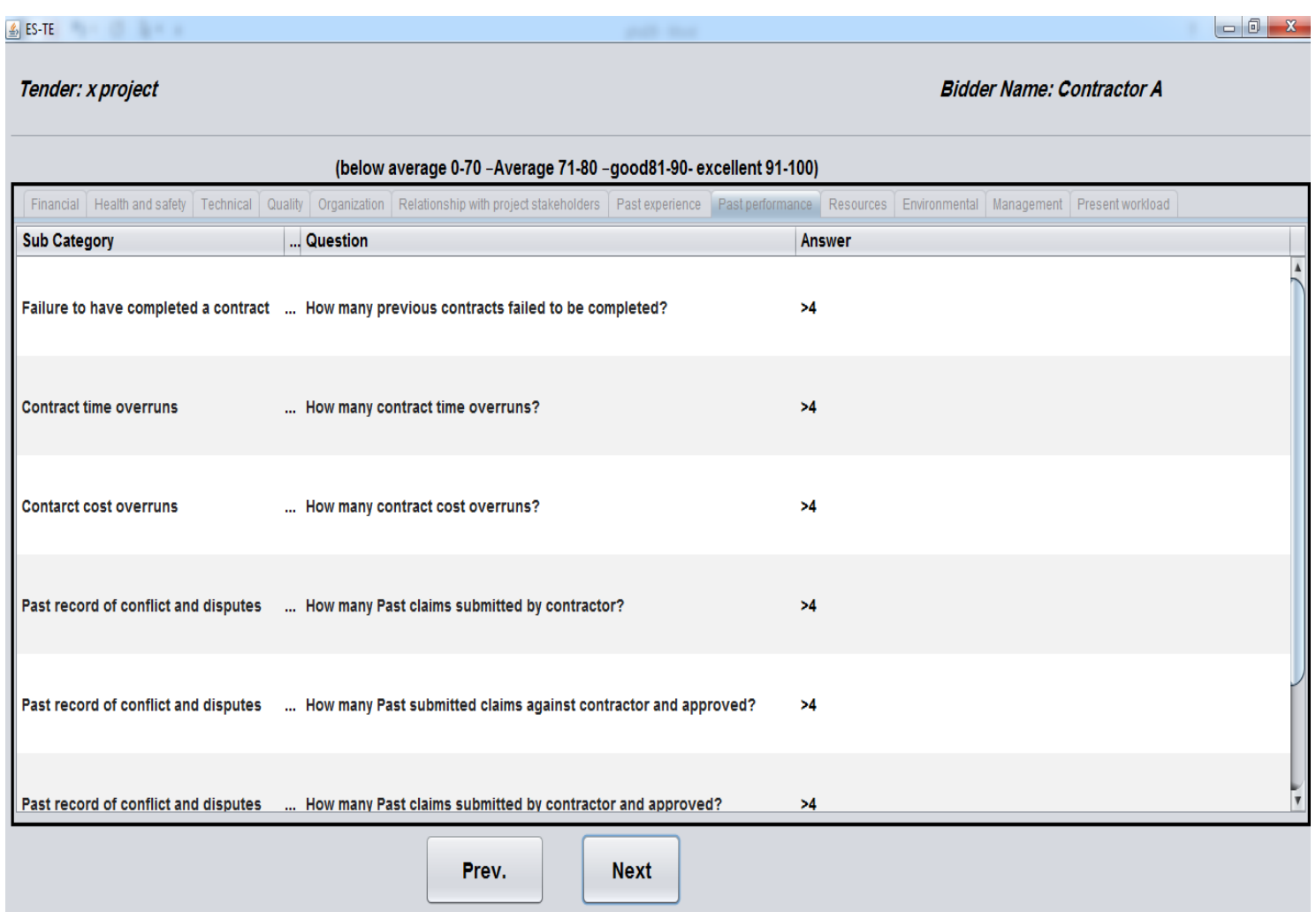

Fig. 12 past performance sub criteria interface screen 


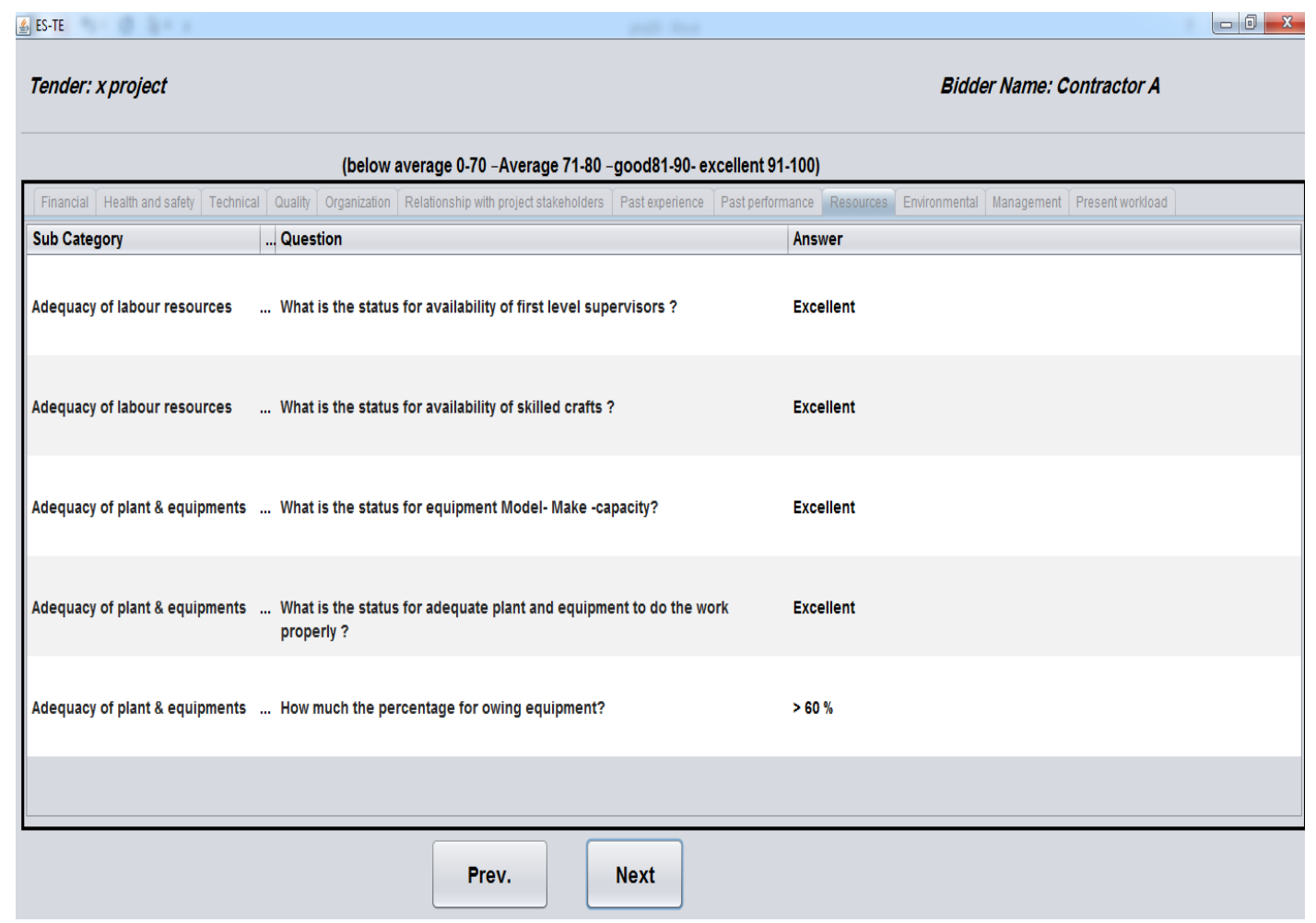

Fig. 13 Resources sub criteria interface screen.

\subsubsection{Present workload}

Then the program goes to the next window present workload. The user will enter no. of ongoing similar projects (see Figure 16).

Then the user will do the same steps for contractor B, C, D. After present workload screen of contractor D the program will generate the following report.

\subsubsection{ES-TE Output Reports for tender no. 1}

Then the program goes to the next window summary report. The result of the contractor evaluation process shows that 'Contractor A' is better than the others in the comparison of quality ranking also 'Contractor $A$ ' is the best one in the price ranking. However, considering both non-price and price criteria, 'Contractor A' is the winner (see Figure 17).

\section{System validation}

Validation can be defined as the process of making sure that the system operates as desired. Nosier (2007), Stated that validation is the process of making sure that the system has a proper level of reality [11]. To check the validity of the expert system, three construction tenders were selected for the purpose of implementing the system. After providing Technical criteria and bid price regarding the three cases study. The results of the three cases study implementation are shown in Tables $2,3 \& 4$. The tables show a comparison between the results from the ES-TE and the actual decision of tender committee. This can give clear picture regarding the validity of the proposed system. 
EXPERT SYSTEM DEVELOPMENT FOR EVALUATING COMPETITION ABILITY OF EGYPTIAN CONSTRUCTION COMPANIES IN INFRASTRUCTURE TENDERS

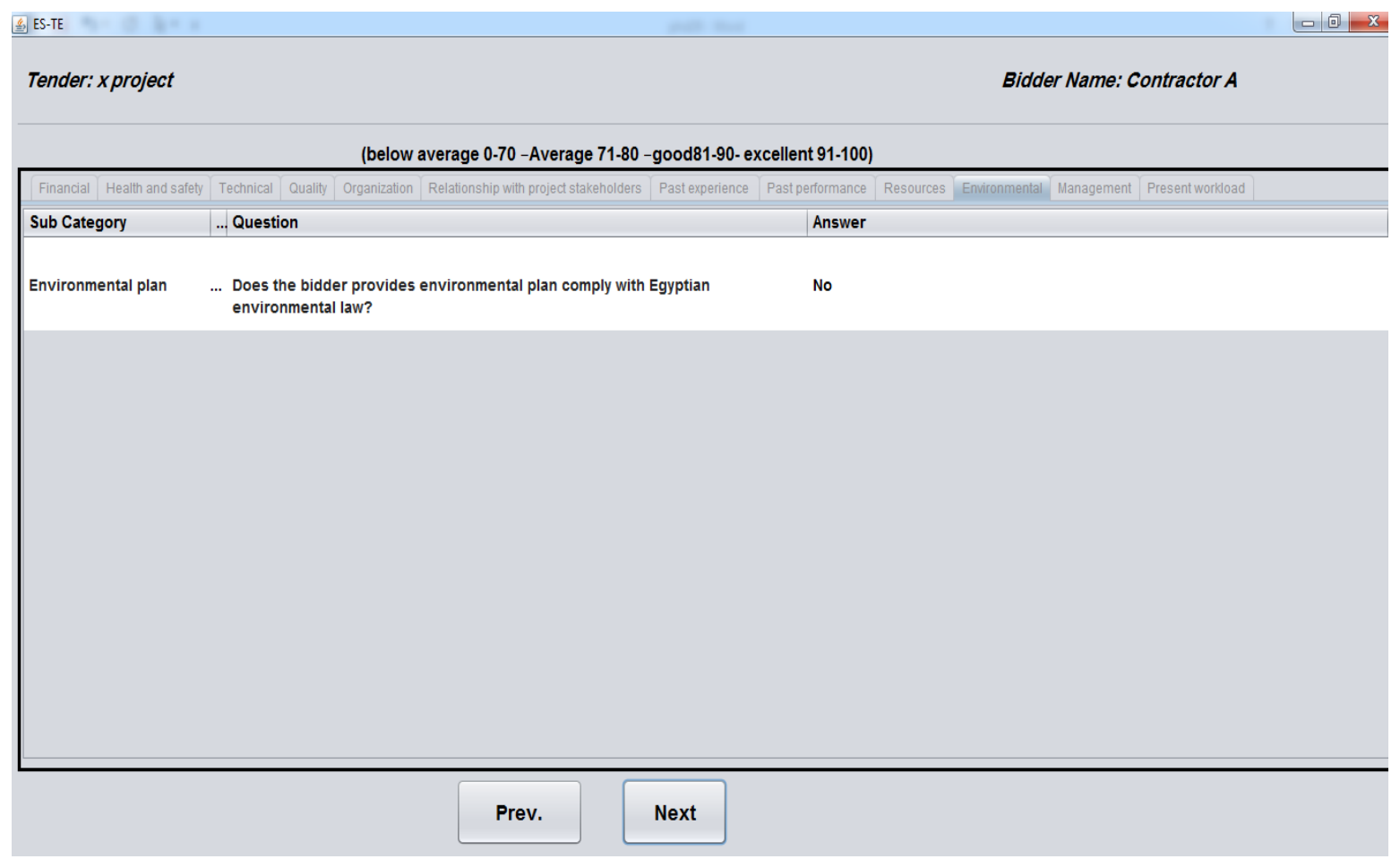

Fig.14 Environmental sub criteria interface screen

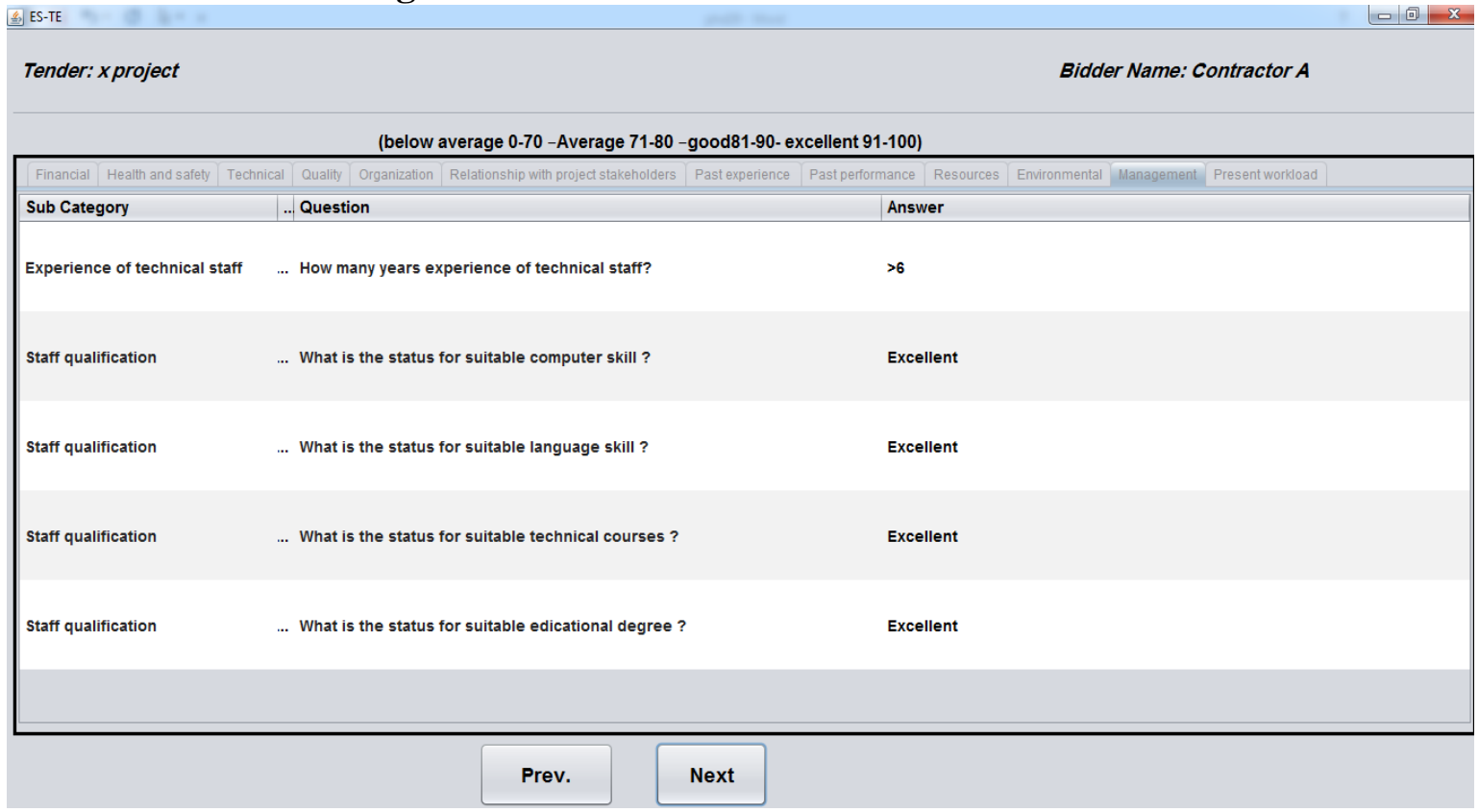

Fig. 15 Management sub criteria interface screen 


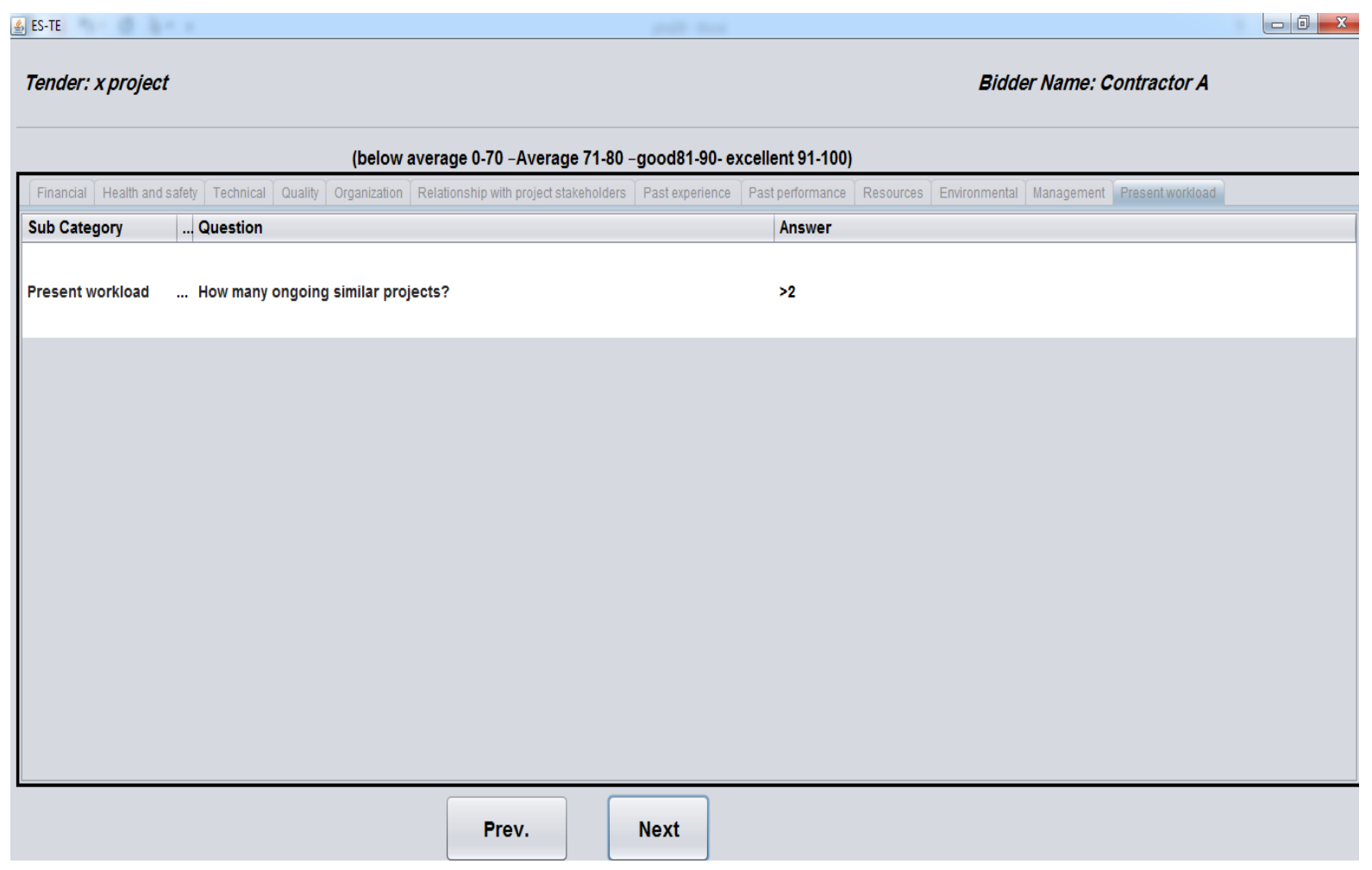

Fig. 16 present workload sub criteria interface screen

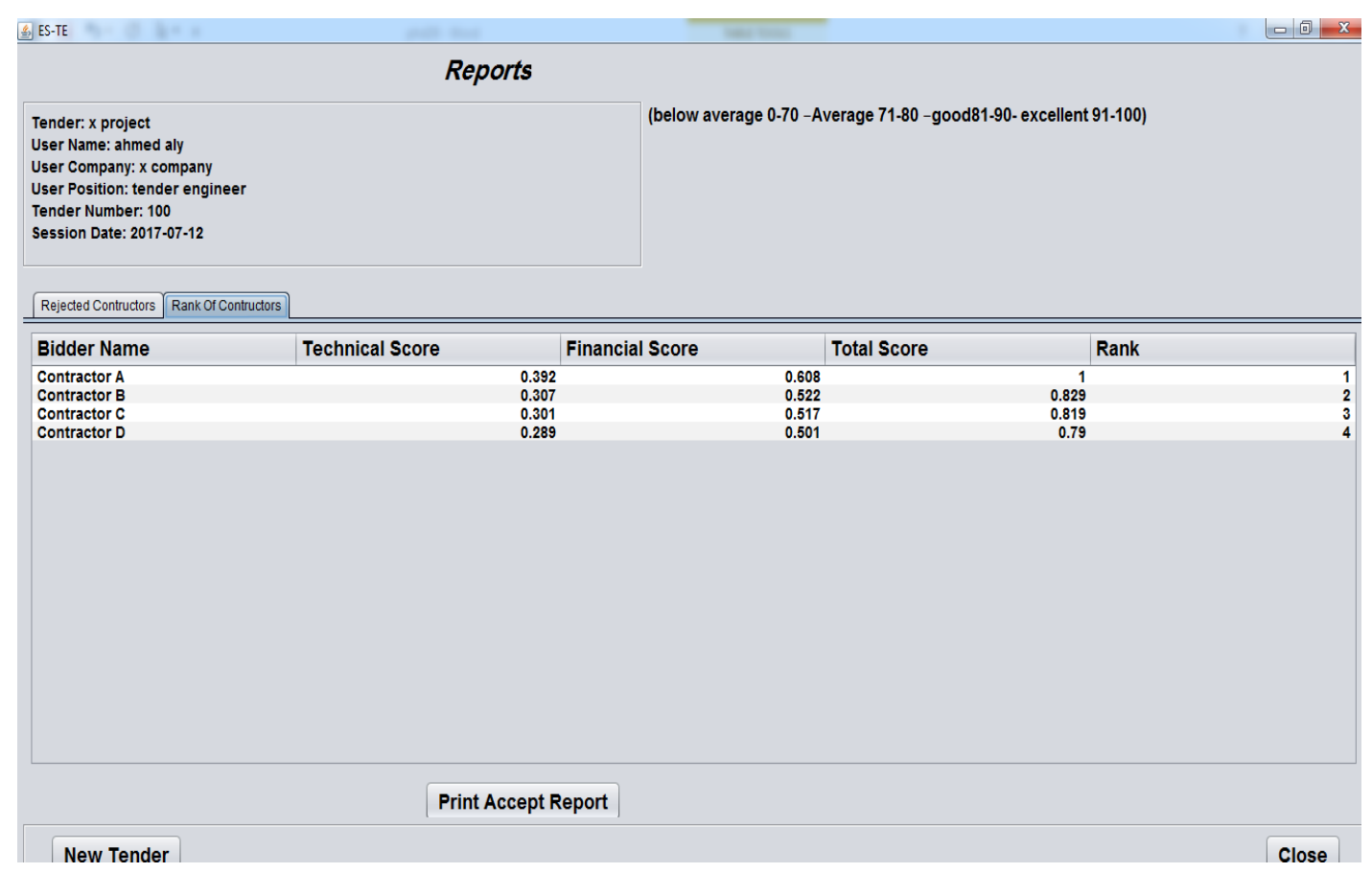

Fig. 17 Reasoning Report screen 
Table 2 Validation for tender no. 1

\begin{tabular}{|c|c|c|c|c|}
\hline Contractor & $\begin{array}{c}\text { Expert system } \\
\text { Score } \\
\%\end{array}$ & $\begin{array}{c}\text { Tender } \\
\text { Committee Score } \\
\%\end{array}$ & $\begin{array}{c}\text { Expert system } \\
\text { Ranking }\end{array}$ & $\begin{array}{c}\text { Tender } \\
\text { Committee } \\
\text { Ranking }\end{array}$ \\
\hline A & 100 & 95.75 & 1 & 1 \\
\hline B & 82.9 & 83.01 & 2 & 2 \\
\hline C & 81.9 & 82.88 & 3 & 3 \\
\hline D & 79 & 81.75 & 4 & 4 \\
\hline
\end{tabular}

Table 3 Validation for tender no. 2

\begin{tabular}{|c|c|c|c|c|}
\hline Contractor & $\begin{array}{c}\text { Expert system } \\
\text { Score } \\
\%\end{array}$ & $\begin{array}{c}\text { Tender } \\
\text { Committee Score } \\
\%\end{array}$ & $\begin{array}{c}\text { Expert system } \\
\text { Ranking }\end{array}$ & $\begin{array}{c}\text { Tender } \\
\text { Committee } \\
\text { Ranking }\end{array}$ \\
\hline $\mathrm{A}$ & 98.1 & 97.7 & 1 & 1 \\
\hline $\mathrm{B}$ & 97.4 & 94.18 & 2 & 2 \\
\hline $\mathrm{C}$ & 88.8 & 83.36 & 3 & 3 \\
\hline $\mathrm{D}$ & 76 & 77.12 & 4 & 4 \\
\hline
\end{tabular}

Table 4 Validation for tender no. 3

\begin{tabular}{|c|c|c|c|c|}
\hline Contractor & $\begin{array}{c}\text { Expert system } \\
\text { Score } \\
\%\end{array}$ & $\begin{array}{c}\text { Tender } \\
\text { Committee Score } \\
\%\end{array}$ & $\begin{array}{c}\text { Expert system } \\
\text { Ranking }\end{array}$ & $\begin{array}{c}\text { Tender } \\
\text { Committee } \\
\text { Ranking }\end{array}$ \\
\hline $\mathrm{A}$ & 88.5 & 78.91 & 3 & 3 \\
\hline $\mathrm{B}$ & 92.7 & 86.47 & 1 & 1 \\
\hline $\mathrm{C}$ & 90.8 & 85.6 & 2 & 2 \\
\hline
\end{tabular}

There are some difference between expert system results and tender committee due to the following:

1 - Difference between weight of expert system criteria and weight of tender committee criteria.

2- There are many criteria in expert system not in tender committee criteria such as environmental

\section{Conclusion}

The system was tested against three actual cases and it is found that the system is valid for assessing the contractor selection in infrastructure tenders in Egypt. The most important criteria were tender price, past experience, resources, quality, past performance financial and technical. Less important criteria were environmental; present workload, Relationship with project stakeholders, Health and safety and Organization. Most important technical sub criteria were Size of past project completed, Type of past project completed, Adequacy of labour resources, QA/QC programs, Adequacy of plant \& equipment's, Present workload, Construction program, Construction method and Environmental. Less important sub criteria were Failure to have completed a contract, Contract time overruns, past record of conflict and disputes, Size of the organization, Length of time in business, Experience in the region and Contract cost overruns. The developed ES-TE is capable to provide comprehensive output reports in two forms: summary and reasoning reports. The reasoning report includes two main paragraphs; one of them rejected bidders the second is the requirement not submitted from the rejected bidder as per tender law .The summary report includes results regarding the bidders rank, total score, financial 
score and technical score. The feature of saving the information whether input or output in case of desire to apply any amendments or start new session. Easy using since it asks user questions and give user many answers and the user choose the suitable answer for each bidder. The benefits of the ES-TE program confirmed that the clients should have program to select the right contractor. The system helps the engineers who have limited experience in handling the contractor selection. Finally, the expert program facilitates contractor selection instead of human judgment.

\section{REFERENCES}

1. Hatush, Z. \& Skitmore, M. "Criteria for contractor selection" Constr. Manage. Econom. 1997 15(1) pp.19-38.

2. Herbert, P. \& Biggart, P." Kingsford Smith Airport, Sydney: Planning and tendering the new Parallel runway", Proceedings of the Institution of Civil Engineers1993, pp.182- 198.

3. J. Alzahran, M .Emsley, "The impact of contractors' attributes on construction project success: A post construction evaluation”, Inter. Journal of project Manage. 2013(31) pp. 313-322.

4. Otaibi,M.\& Price,A. "Analysis and evaluation of criteria for pre-selecting contractors in the Saudi Arabian construction sector", Procs 26th ARCOM Conference, UK; 2010.

5. Hatush, Z. \&Skimore, M, "Evaluating Contractor Pre-qualification Data: Selection Criteria and Project Success Factors ", Construction Management and Economics 1997 15(2) pp. 129-147.

6. Eddie,W.\&Heng,L. "Contractor selection using the analytic network process", Construction Management and Economics 2004(22) pp. 1021-1032.

7. Palanceswaran, K.\& Kumaraswamy,M. "Construction selection for design/build projects", Constr. Engr. and Manage. 2000126(5) pp. 331-339.

8. Asce, L., Lu, W., Yam M. \& Asce, M. "Contractor key competitiveness indicators: A china Study", Constr. Engr. and Manage.2006 132(4) pp.416-424.

9. Watt,D., Kayis,B. \& Willey,K. "The relative importance of tender evaluation and contractor selection criteria", Inter. Journal of Project Manage. 2010(28) pp. 51-60.

10. Elsaid, A. , Abdelhamid, M. \& Nosaira, I. " Competition ability criteria for Egyptian construction companies in infrastructure projects", In Procs 1 icscpm16 Conference, Egypt; 2016. 11. Nosair, A. "Exscd an expert system for construction disputes". Mansoura Eng J 2007;32(17):C.48-58. 